\title{
DECOLONIZING THE ARCHIVES: THE WORK OF NEW ZEALAND'S WAITANGI TRIBUNAL
}

\author{
RACHEL BUCHANAN
}

PUBLIC HISTORY REVIEW, VOL 14, 2007, PP44-63

\begin{abstract}
$\mathrm{A}^{\mathrm{s}}$ rchives make history. Public records are the foundations on which academic historical work has been built. Letters written in faded Indian ink, pencil doodles in the back of account books, ministerial telegrams in secret code, parliamentary records printed in six-point Times Roman on paper finer than onion peel, silvered glassplate negatives, the whoosh-zoom-stop hunt through newspapers on microfiche, grainy stereographs so thick beneath the fingers, all those precious, foolish, priceless, worthless old words and pictures numbered and protected and stored away, waiting for us to find them. Archives charm. Archives harm. Beyond their tactile, anachronistic or nostalgic appeal, archives are part of the architecture of imperialism. They are sources of narrative power, sites where stories about the bloody or bloodless beginnings of a nation are stored. The archive is also a place of discursive or epistemological violence, a place where one way of knowing the world - the spoken - was replaced with another, the written. ${ }^{1}$ Writing about India, Bernard Cohn has argued that the establishment and maintenance of European nation states 'depended upon determining, codifying, controlling and representing the past'. ${ }^{2}$ The documentation required to do this forms the bulk of colonial archives. Colonial history emanated from archives and, as Antoinette Burton has observed, in times of threat, history returns to the archive to reassert its authority as a scientific, objective, empirical source of knowledge. ${ }^{3}$

But what, exactly, is history returning to? Could it be that the archive is as unpredictable and fluid as the history that emanates from it? Writing about Aotearoa New Zealand, Linda Tuhiwai Smith has argued that in the nineteenth century history and imperialism were bound together as modernising forces that justified one group's exploitation of another. Therefore, 'rewriting and rerighting history' is an important part of decolonisation. ${ }^{4}$ If history is to be decolonized, then the archives it is made from must be too. Reading existing archival documents in new ways, hunting out the silences, biases,
\end{abstract}


lies, pride and oversights that infuse written evidence, is not enough. New archives are required and the definition of what qualifies as archival must be broadened and democratised. This article uses the work of the Waitangi Tribunal in New Zealand to explore how this might be possible. It argues that archives, like the nations that created them, are not fixed and stable. Archives are as much a product of their time as histories. They are collections of documents that result from an interplay of public and private, local, national and international forces. Since the 1970s, indigenous people in Australia, New Zealand and elsewhere have pressured settler governments to acknowledge colonial crimes and make compensation for them. This process of reconciliation, reparation and restitution is part of what might be called a journey towards anti-colonial nationhood. In New Zealand, the public work of reconciliation has been carried out, predominantly, by the Waitangi Tribunal, a permanent commission of inquiry set up in 1975 to investigate allegations of contemporary breaches of the Treaty of Waitangi. In 1985 , the tribunal was given retrospective powers so it could investigate breaches dating back to the initial signing in $1840 .^{5}$

The tribunal is a mammoth and ongoing public history-making project. In its first thirty-one years, the tribunal has published more than ninety reports in response to the hundreds of contemporary and historical claims lodged before it. But the published reports represent only a fraction of the tribunal's work. It is not my task here either to debate the merits or failures of the claims and settlement process as a forum for 'rewriting and re-righting' history or to analyse the kind of history produced by tribunal reports. Many others have done this, arguing, among other things, that reports are presentist, counter-factual, a form of impoverished victim history. ${ }^{6}$ The work of the tribunal is necessarily constrained by its brief to investigate post-contact grievances but the voluminous and precious archives generated by tribunal inquiries and by the settlement process that sometimes follows them, provide the seeds for other more satisfying and challenging stories about New Zealand's past and present. ${ }^{7}$ Tribunal hearings are incredibly rich and layered sites of public history-making and a hearing's archive reflects this richness. It is an archive bursting with feel that includes historical reports written by tribunal historians, historical reports written by Crown historians, 'traditional' tribal histories written and performed by Maori claimants, non-traditional histories written by 'professional' historians commissioned by claimants and personal testimonies by Maori claimants.

Oral testimonies have generated the most commentary because they slot into a large body of scholarship concerned with indigenous oral history and memory. ${ }^{8}$ In a recent analysis of the historical problems posed by the tribunal's work, Miranda Johnson has argued that Maori oral testimonies are more than a supplement to fill gaps in the documentary archive. Rather, they 'displace the central legitimacy of the written documentary record, and require us to rethink the boundaries of the archive. ${ }^{9} \mathrm{By}$ 
collecting the family and tribal histories and songs that Maori claimants have chosen to share, the tribunal has made the private public. In the process the colonial archive has been expanded, democratised and decolonised. The histories embedded in waiata (songs), in whakapapa (geneaology) and in the names of people, places and buildings have always been performed on marae (Maori meeting places) in te reo Maori. Language alone made this knowledge difficult for non-Maori-speaking historians to access. Written records, such as whakapapa books or the writings of tribal scribes, have been held within families and the knowledge they contain has been shared only with a select few. ${ }^{10}$ This transfer of some knowledge from the relatively private and often - but not always - oral domain of the Maori world to the public one of a government-funded and maintained documentary archive is a gift that is yet to be fully acknowledged by historians. ${ }^{11}$

Here, I examine some of the archival material generated by the Taranaki inquiry, but not included in the published tribunal report. ${ }^{12}$ The testimonies focus on stories about Parihaka, New Zealand's largest nineteenth-century Maori town, a pan-tribal settlement that was home for up to 3000 followers of the pacifist teachings of prophets Te Whiti o Rongomai and Tohu Kakahi. ${ }^{13}$ In 1881 , Parihaka was invaded by 1500 soldiers and militiamen. In a subtle demonstration of moral and practical power, the troops were 'welcomed' by singing and dancing children and women carrying fresh bread. The two leaders did not resist their arrest nor did residents use violence to prevent the destruction of much of the village or their own eviction. Examining the tribunal archives allows an academic historian such as myself to create new histories but it also challenges conventional markers of academic historical practice, most notably the disjuncture between past and present. Academic history continues to function on the understanding that the past is different and distant from the present and that studying the past means studying an event or series of events that took place in that past and are, therefore, completed. Academic history operates within an understanding of time that is secular, rational, objective, scientific, progressive, distancing, empirical. Bain Attwood has described the process in 'conventional historical work' as being one in which 'the historian, deemed to be an outsider, strives to represent the past as it happened and to realise the past's alterity - its difference from present times'. ${ }^{14}$ Another distancing strategy in conventional history is to think about 'causes' and 'origins' of a particular event rather than what happened afterwards, to 'concentrate on what leads up to the past rather than on the consequences of that past'. ${ }^{15}$

Dipesh Chakrabarty has argued that minority or subaltern pasts unsettle these understandings of history. Such pasts, he writes, are 'stubborn knots' that break up 'the otherwise evenly woven surface of the fabric' of Western historical time. Minority pasts are more likely to be non-linear, heterogeneous and infused with the spiritual forces and human and non-human actors. ${ }^{16}$ The 'subaltern' histories shared at tribunal hearings 
knowingly collapse distinctions between past and present, placing 'historical actors' and 'historical events' on the same stage as present ones. These understandings of history are sometimes reflected in the language of tribunal reports too. Claimants challenge listeners to hear what they are saying about the way 'European history' has been implicit in colonisation. But how does a historian use historical evidence which refuses to locate 'the past' in the past? When did colonisation occur in New Zealand? In the nineteenth century? The twentieth century? The twenty first? Is it possible to write a history of something that is not over yet? These are some of the questions that arose for me as I read the tribunal's emotion-saturated Taranaki report and then explored the archives this report had generated.

\section{THE TARANAKI REPORT}

Taranaki is a province on the West Coast of the North Island, a place distinguished by its mountain, Taranaki, a peak whose awesome symmetry is surpassed only by Mt Fuji in Japan. The Taranaki claims were heard at twelve sittings at various marae and motels in the province between 1990 and 1995. Two sittings were held at Parihaka, a settlement much diminished from its nineteenth-century wealth and magnificence. About 200 people live there now. The Taranaki hearings grouped together twenty-one claims relating to the province of Taranaki. Claimants identified with one or more of ten Taranaki iwi Taranaki, Te Ati Awa, Ngati Tama, Ngati Mutunga, Ngati Maru, Nga Ruahine, Ngati Ruanui, Nga Rauru, Tangahoe and Pakakahoi - and their grievances all resulted from the land confiscations that followed the 1860s wars.

The Taranaki claims and subsequent 1996 report were the tribunal's first historical investigation into the confiscations inflicted on Maori across the North Island. The report found in the claimant's favour and argued that the Taranaki claims could be the largest in the country because 'there may be no others where as many Treaty breaches had equivalent force and effect over a comparable time'. ${ }^{17}$ Armed conflict lasted for nine years in Taranaki - from 1860 until 1869 - the longest of any district in New Zealand, the report found. If the definition of armed struggle was broadened to include the first signs of conflict in 1841 - the year after the first boat of white settlers arrived - and the 1881 invasion of Parihaka, then 'conflict over the use of arms was not spread over a few months, as in most places, or even over a decade, but over a staggering forty years. ${ }^{, 18}$

The report represents the invasion and sacking of Parihaka as the central catastrophe in a catastrophic site. The invasion 'must rank with the most heinous action of any government, in any country, in the last century. For decades, even to this day, it has had devastating effects on race relations'. ${ }^{19}$ The intensity of the tribunal's narrative of loss is demonstrated by the controversial use of the word 'holocaust' in connection with Taranaki. ${ }^{20}$ The report concludes with statements that reveal how the tribunal's understanding of colonisation sits between what might be called academic historical 
perspectives - colonisation is an event that happened in the nineteenth-century past and a more subaltern view - colonisation is an event that has never stopped happening. The report's conclusion said:

As a quantam, the gravamen of our report has been to say that the Taranaki claims are likely to be the largest in the country. The graphic muru of most of Taranaki and the raupatu without ending describe the holocaust of Taranaki history and the denigration of the founding peoples in a continuum from 1840 to present. $^{21}$

A gravamen is Latin word connected with biblical history. It is 'the part of an accusation which weighs most heavily against the accused; the burden or substantial part of a charge or complaint. ${ }^{22}$ Muru is plunder and raupatu is the word Maori use to describe the confiscation of land although in Taranaki these words have slightly different meanings: muru describes land confiscated in war and raupatu describes land confiscated through perpetual leases. ${ }^{23}$ For Taranaki Maori, the tribunal asserts, raupatu describes their 'marginalisation by the organs of the State, for on this view, they were never conquered by the sword but were taken by the pen'. ${ }^{24}$

Despite this statement, the tribunal's report focuses overwhelmingly on the injustices inflicted on Taranaki Maori during the nineteenth-century wars, especially the devastating impact of the Parihaka invasion. The sword, in the report, is mightier than the pen. But a small historical submission prepared by a Taranaki claimant, drawing on existing archival evidence - departmental and local government archives - and local knowledge - the archives contain information relating to the claimant's relatives and neighbours - reveals just how recently the pen has enacted its colonising work.

\section{THE LIGHTHOUSE}

In her careful and stimulating discussion of what she terms 'the paradox of Maori agency', Giselle Byrnes argues that Maori appear before the tribunal as 'obligatory victims'. ${ }^{25}$ A booklet for claimants written by the tribunal's chief historian Dr Grant Phillipson explains the process. 'Claims to the Waitangi Tribunal are complaints,' the booklet begins. The complaint has two parts. First, that the Crown has breached the Treaty by its laws, policies, actions or inaction. Second, that Maori have been harmed by these breaches. ${ }^{26}$ In Taranaki, Maori carefully scripted their testimonies to demonstrate both the harm caused by Treaty breaches and the way they had resisted this harm and found creative ways to sidestep Pakeha authority and maintain their authority over tribal land. Their testimonies are stories of victims and of people who refused to be victimised. They demonstrate what has been lost but they also demonstrate how tenaciously Maori 
clung to what was theirs and how local, informal agreements allowed Maori to continue to use and care for their land many decades after it had been 'colonised'.

At Parihaka, Taranaki claimant and tribal historian Te Miringa Hohaia and researcher Marlene Benson presented the tribunal with a history of the block of land on which the 'Cape Egmont Lighthouse' stands. The lighthouse is a few kilometres south of Parihaka. In the nineteenth-century, the installation of utilities was one way that imperial powers colonised by stealth. In Taranaki, settler politicians saw the construction of the lighthouse, the telegraph and the road as powerful symbols of their supremacy. The military installation of the lighthouse - the whitest of sentinels - was regarded as a particular triumph in the peaceful settlement of the so-called 'native difficulty' in Taranaki. A lighthouse had first been recommended for this treacherous cape in 1861 but war between Maori and the British Crown made construction impossible. This coast was Maori territory and passengers on the many ships wrecked there relied on Maori goodwill to survive. In 1880, a detachment of soldiers engaged in the military campaign on Parihaka, marched to 'Cape Egmont', fenced off paddocks where Maori grew crops, and supervised the construction of the lighthouse. It was illuminated in August 1881, a few months before the invasion of Parihaka. ${ }^{27}$

But Hohaia and Benson's case study of the lighthouse reserve is a more complicated story in which settler triumph is deferred well into the twentieth century. ${ }^{28}$ The fate of this block of land challenges the tribunal report's hegemonic narrative of the 1881 invasion of Parihaka as the single, dramatic and stereotypical colonising moment in Taranaki. It also counters the more popular notion that colonisation occurred in the nineteenth century, and therefore it is not something that Pakeha alive now should be responsible for. What the lighthouse history reveals is that in one pocket of Taranaki at least, colonisation was resisted not by two charismatic Maori prophets but by an elderly woman with a rent book. Conversely, the colonisation of this bit of land was achieved not by an evil government minister and his army but by an anonymous bureaucrat. It was a slow, insidious, incremental and terribly ordinary thing achieved in an office rather than on a battlefield.

The long-standing Maori occupation of much of the lighthouse site suggests that the political effect of the construction of the lighthouse was perhaps not as great as the government might have hoped for in 1880. As documents collected by Hohaia and Benson tell it, six years after Parihaka was invaded, Te Whetu Moeahu, a Parihaka leader, negotiated an excellent deal with the government - approved by the Defense Minister, no less - to lease eighteen acres of the reserve from the Marine Department for a nominal annual rent. The deal was formalised when Te Whetu signed a warm letter from a Mr J. Pardy, inspector of police in New Plymouth. It was conditional upon Te Whetu remaining 'of good behaviour'. And so, Maori lived there by the lighthouse and grew kumara, potatoes and pumpkin. When Te Whetu died in 1896, the lease was taken 
over by his widow, and Maori continued to live on the land and farm it, maintaining their presence through negotiations with the Marine Department.

After Te Whetu's death, the department had wanted to use all the reserve but Maori objected. This objection was noted and Maori 'continued to occupy a portion of the reserve for the purpose of growing their crops, and the Department has never interfered with them'. ${ }^{29}$ They also trapped eels in a 'good lamprey stream in the neighbourhood'. By the early 1930s this co-existence was being threatened. Pakeha farmers had made offers to buy the land. Maori should pay more for the lease, they argued. They should control the weeds - namely non-native introduced plants like gorse and lupins - and fence the stock. The local council, the Egmont County Council, complained that Maori were squatters. 'It has been suggested that this land should be available to the public as a seaside reserve', the County clerk wrote. ${ }^{30}$ In the 1940s, when Mrs Te Whetu died, the lighthouse lease was taken over by Louie Okeroa.

In 1951, Hohaia and Benson's account shows that Mrs Okeroa negotiated a new lease with the Marine Department. Again, neighbouring Pakeha farmers offered to buy or lease the land. The Commissioner of Crown Lands stepped in. A field officer was 'not very enthusiastic in respect of the proposed lease to a Maori'. ${ }^{31}$ Mrs Okeroa went to the Lands and Survey office in New Plymouth to pay her new rent of nine pounds and five shillings but she was told to go to the Marine Department offices. Neither office would accept her money or let her sign the lease. The unsigned document, with Mrs Okeroa's personal details typed neatly at the top, is included in Hohaia's report. With the rent unpaid and the lease unsigned, the land was subsequently surveyed and sold to Pakeha farmers.

And so, after seventy-four years, the Crown and settlers had finally possessed the lighthouse site. The documents that chart this loss reveal certain persistent Pakeha beliefs about Maori, most particularly the myth that Pakeha use of land is productive while Maori use is unproductive. These beliefs connect with broader racist ideas that describe indigenous cultures as 'economies of waste'. ${ }^{32}$ In 1952, for instance, a Marine Department field officer had inspected the lighthouse site and found 'that the land in question is a good piece of land but through neglect of the licensees has been allowed to almost revert to lupins etc; also it is not fenced in on the western boundary so that the control of stock is not possible'. ${ }^{33}$

In the nineteenth century, Taranaki Maori had been described in terms of excess. There were too many of them, they had too much money, too much land and too much power. They were wasteful rather than provident and careless about the future. These statements overlooked the extensive, well-fenced and tended, cultivations and herds of stock that Maori maintained around Parihaka. Settlers were blind to Maori farming. Instead, Maori farms were seen only as obstacles in the path of progress - the West Coast road - so Crown troops repeatedly tore down fences and destroyed or plundered 
crops. In 1881, then, Maori fences and crops were criminal impediments to progress. Yet in 1952, it was the very absence of these things that was punished. These are some of the contradictions of 'colonisation' illuminated by the study of the lighthouse site that Hohaia presented to the tribunal. The history of the lighthouse site reinforces the trajectory of colonisation - the site was eventually possessed by Europeans - but it leaves spaces for stories that challenge this trajectory too.

The lighthouse report is an example of the way the tribunal process has allowed existing archives to be used in new ways. Hohaia's family history meant he knew the lighthouse site had been used and cared for by Maori well into the twentieth century, a fact that runs counter to public narratives about Parihaka that situate dispossession in the nineteenth-century. ${ }^{34}$ The documentary record provided the evidence to support family stories. The documents, therefore, are no longer authored solely by Pakeha departmental and local government officials; their inclusion in the tribunal archive means they are 'authored' and 'author-ised' by Maori too and they become part of a story that extends far beyond one hazardous stretch of coastline into bigger debates about national historical narratives that locate colonisation in the nineteenth-century.

Before tribunal hearings, Maori claimants steadfastly refused to place colonisation in the past, thus questioning the 'historical' nature of the tribunal's inquiries. In its report, the tribunal observed that the story of Parihaka was regularly retold at the pa where 'striking photographs of the old village and invaded army are still maintained in the hall on the hill':

There was much pain and anger in the submissions of many who spoke of Parihaka. They challenged the Pakeha written record as inadequate and culturally biased and they would offset it with family accounts passed down orally. We have had regard to this evidence. We were constantly aware, from listening to the people, that the story of Parihaka is no past account but part of a living tradition. ${ }^{35}$

A local whakatauki (saying) explains the way time enfolds in some Maori testimonies, signaling an understanding of time that is circular rather than linear, a 'living' history rather than a 'dead' one.

Koia kei a ia te wa aianei

Koia kei a ia te wa a muri

Koia kei a ia te wa a muri

Koia kei a ia te wa a mua

Wa muri ka oti a mua 
He who holds the present holds the past He who holds the past, holds the future The past of our ancestors is our future Rocky Hudson, whakatauki na Aotea waka ${ }^{36}$

New futures are possible when the past is understood in new ways. For this to happen, the claimants appeared to insist that the boundaries between what is understood as past and what is seen as present be collapsed. Such a shift is not always easy to make.

\section{A FAILEd Apology}

Misunderstandings about the 'historical' nature of the grievances being aired at Parihaka before the tribunal are revealed in a tortuous exchange over an apology contained in the tribunal archives. Negotiated apologies have since become a powerful and significant part of 'Deeds of Settlement' between iwi and the Crown but in the early 1990s, apology protocols had not been developed and there was much space for misunderstanding. ${ }^{37}$ When the Waitangi Tribunal sat at Parihaka for the first time in 1991, a representative of the Crown offered an apology for the 1881 invasion and sacking of the village. Solicitor Tom Winitana, a Tuhoe Maori, spoke on behalf of the Minister of Justice, Pakeha Doug Graham.

Winitana said the Crown did not dispute Taranaki claimants' testimony about the sacking of the village at the $1927 \mathrm{Sim}$ Commission, an earlier government inquiry into land confiscation, and it did not dispute claimants' version of events now. The Crown would listen respectfully if people chose to talk about the invasion but it did not expect 'any one of you to come before this Tribunal and suffer the distress of re-telling those events.' Rather, Winitana concluded, the Crown was ready to enter into direct negotiations with Taranaki iwi to 'discuss any proposal whereby the mana (status) of Parihaka might be restored.

We are the descendents, the inheritors of that unhappy past. It is our duty to give it a proper burial. It is my duty, as one of Her Majesty's Ministers, to apologise to the ancestors of Parihaka and I now do so. In doing so I look now to the future. It beckons us all. Let us stand together as we face what is to come. ${ }^{38}$

Parihaka leaders did not accept this well-meant but rather abrupt apology. It had come without warning, they explained, almost as an afterthought. It was addressed to the dead rather than the living, the descendants of those who had 'lived through the sacking and looting and destruction of Parihaka'. If an apology was to be offered to the living, it would 
have to be an event of national significance - rather than local, low-key gesture because Parihaka itself had been a gathering place for iwi from beyond Taranaki. It would have to be offered to a large audience that included Maori from around New Zealand rather than the smaller group of Taranaki people assembled for a tribunal hearing. Parihaka is, in many ways, an exceptional place believed, by many, to be New Zealand's only inter-tribal marae. ${ }^{39}$

As Parihaka leaders wrote: 'The hurt of Parihaka is therefore felt far beyond Taranaki. What happened there was something of an affront to nations. To the nations which embraced each other as Treaty partners in 1840.40 The timing and form of the apology would need to be negotiated between the Crown and the people of Parihaka. The bearer of the apology should have a status that matched the status accorded to the invasion of the village, an invasion that 'took place at the direction of the highest authorities'. 41

In response, Minister Graham wrote that he was 'deeply disturbed' his apology had been rejected. He had been acting in good faith and believed that his 'personal apology to your ancestors' would demonstrate to Parihaka people that 'as Her Majesty's Minister responsible for Treaty claims I was listening to their grievances with sympathy and understanding'. ${ }^{42}$ The apology was undoubtedly well-meant but it was not addressed to the right audience. In the fifteen years since the Parihaka hearings, negotiated apologies encompass the living, the dead and those yet to be born. Far from being a 'burial', an apology is supposed to signal the beginning of a new partnership between the Crown and the iwi in question. A recent settlement of 'historical claims' between the Crown and Ngati Mutunga, one of the ten Taranaki claimant iwi, contains an apology 'to Ngati Mutunga, to their ancestors, and to their descendants'. ${ }^{43}$ Such apologies represent a radical upturning of the concepts of 'history' and 'historical grievance'. The personal testimonies of Taranaki claimants contained in tribunal archives reveal how the past 'vibrates' in their present and flow on into their future.

\section{'THE QUIVER ON THE BOUGH'}

Lindsay Rihari Waitara MacLeod, who opened the testimony for Taranaki iwi claimants at both Parihaka hearings, said that the words of nineteenth-century Parihaka leaders Te Whiti and Tohu continued to teach Maori not to be 'bitter and vindictive'. ${ }^{44}$ MacLeod described nineteenth-century Parihaka by quoting a 'O Rere Raa', a lament composed in the 1880s for Tohu by Muapoko people. ${ }^{45}$ MacLeod explained what the song was about: 'Everybody's on the move, they come from near and far to listen to the word of the Prophet, they highlight the climb to the Purepo where the Cannon stood (Mt Rolleston) to blast them out of existence thence down to Toroanui Marae to listen to the "seething oratory and sweet talk".' 
MacLeod's translation of the song provided a commentary on the two histories embodied in many Taranaki landmarks. At Parihaka, for instance, locals call a hill overlooking the pa (settlement) Purepo 'the hill of cannons' whereas Pakeha know it as Mt Rolleston, the name of one of the government ministers involved in the raid on Parihaka. At the second Parihaka hearing MacLeod reiterated this point about two kinds of history at work in New Zealand. Further, he assumed that the present-day claimants who stood before the tribunal were not separated from the people who stood at Parihaka on the day it was invaded. MacLeod promised, at the end of the submissions 'to describe events on that fateful dramatic day when we (our ancestors, Tupuna, Te Morehu) faced the threat of death itself by the dreaded Cannon strategically placed on the hill overlooking the $\mathrm{Pa}$, the Purepo, now known in "European history" as Mt Rolleston. ${ }^{46}$ 'Te Morehu' is the expression Maori use for 'survivors' both of the 1881 invasion and to describe themselves now. Therefore, the 'we' in MacLeod's statement includes the living and the dead.

MacLeod described nineteenth-century Parihaka as a home for hapu (large family groups) and iwi from around Aotearoa. It was like a miniature version of the nation, a spiritual and practical home. Waikato, Maniapoto, Wanganui, Muapoko, Te Ati Awa 'each had their own houses with Ancestral names such as Rangiatea, Koaiai... each with their unique mode of Prayer chanting psalms while twirling their pois.' Kumara and kamo kamo (a kind of cucumber) was grown on beach reserves and fish was gathered in open surf boats and people such as Te Rangiwakarurua distributed the fish at Parihaka, giving each family group what they needed. This harmony and cooperation was destroyed by 'the blitz', the invasion of the village.

For simply defending their 'house and home' they were declared REBELS, exiled and imprisoned without trial in Otago between 1869 and 1881. Housed and worked in caves like slaves and had large tracts of land confiscated. Some never returned but died in ignominy.

The devastating breakup of their whole social structure and peaceful lifestyle are seen in our kids of today, who are social and psychological misfits and refugees culturally in their own land with their economic base taken from underneath them. ${ }^{47}$

He concluded by naming the people - living and dead - who had provided him with his evidence. His informants included Tahuaroa Watson, the adopted son of Taare Waitara, the man who funded much of the post-invasion restoration of Parihaka. His testimony ended with a proverb and statement that reinforced the continuity between past and 
present generations at Parihaka, a continuity that was expressed through descendents ongoing adherence to the teachings of Te Whiti and Tohu. A proverb of Te Whiti is translated as:

'The bird startled has flown, only the quiver of the bough remains.'

We are the quiver - their descendants whom despite all their pain and hurt and feelings on injustice, never taught us to be bitter, vindictive or take revenge but on the contrary - Give Glory to God in the Highest, Peace on Earth and Goodwill to all Mankind.

Thank you for your patience 'Ka Aroha - Ka Tangi Au Kia Ratau. ${ }^{48}$

MacLeod's testimony reinforced the ongoing importance of Parihaka as both a place and a value system, a site of moral power for Maori.

In his submission at Owae Marae, Donald Hugh McDonald makes a similar point. His testimony is a heart-wrenching story of a family who have been so damaged by the loss of Maori land that many 'feel more comfortable being Pakeha'. It was too difficult to take up the responsibilities of 'gathering the family together and enhancing iwi development'. McDonald, the fifth son in a family of fifteen said it was traditionally the job of his four older brothers to lead and support but

the places where we used to gather food at certain times of the year are no longer places of sustenance and support. One is made to feel like an intruder when we have to ask pakeha if we could have ready access to the places we used to go for generations, to gather watercress, preserve our corn, fish for eels, or dye harakeke in the black mud... we used to have ample land to sustain all our families... the resources have gone. ${ }^{49}$

McDonald's submission ends in Maori but the final English comment is a plea to the Crown to put things right and the comment: 'I firmly hold to the teachings of Tohu Kakahi and Te Whiti o Rongomai.' In this context, Parihaka is evoked as a signal of the speaker's forbearance in the face of remarkable adversity and as a pledge of ongoing resistance and protest. Inherited struggles, often connected with nineteenth century events at Parihaka, was a common theme. Between 1863 and 1947 Taranaki Maori alone made 169 petitions to government pleading for the return of land.$^{50}$ One way that claimants demonstrated the continuity of their resistance, the 'living' nature of the history being shared, was by using their whakapapa to provide a genealogy of protest that 
preceded the speaker's life and would continue, if necessary, after the speaker's death. Ngatata Love ended his submission by introducing the four generations of his family at the hearing.

Let there be no doubt in the minds of the Crown that this injustice will not die or disappear. Taking the lead from our kaumatua, Sir Ralph, who fights the case at 85 , the next generations are selected and ready to continue the struggle until at least 2060 .

\begin{tabular}{|c|c|c|}
\hline Makere & 85 & \\
\hline Ngatata & 5331 years & 2021 \\
\hline Catherine Amohia & 3055 years & 2045 \\
\hline Sharmia & 1075 years & $2060^{51}$ \\
\hline
\end{tabular}

One of the measures of family member's life is the number of years they will be able to continue the struggle. A similar measure was used by Peter Moeahu who introduced his first-born grandchild, Moeahu Edwards, as 'an offspring of Taranaki and Tainui, two iwi who suffer much from confiscation of their land. We recently gathered at our family marae to celebrate the christening of my mokopuna. The name of her marae in Taranaki is Muru Raupatu (confiscation and marginalisation). ${ }^{, 52}$ In Moeahu's testimony, various marae have been places for learning about injustices. At Muru Raupatu, for instance, he learnt how his great-grandfather, Tamati Whanganui had been imprisoned for ploughing family land 'just north of Bell Block' as part of the Parihaka protests.

At Te Niho on Parihaka, he had learned from his grandmother and other female relatives about 'the wonder and tragedy of Parihaka', how it had been a place of refuge and plenty, surrounded by 'land so fertile that it sustained all who gathered' there.

Finally, at Te Aroha marae, he learnt about the warrior Titokowaru and how Moeahu, an ancestor, had carried Te Whiti's words of peace to him and how Titokowaru eventually 'turned to Parihaka for peace'. The destinies of these three marae were intertwined, 'like the Te Raukura, the three feathers of Te Whiti, they stand as a reminder of the 'the immeasurable beauty that could have been, and the desolation and suffering that is' ${ }^{53}$

These testimonies, in which peaceful Maori resistance and protest are one way of continuing the traditions of Parihaka , are absent from the Taranaki report. So too are the non-human historical actors which are a significant feature of some testimonies. ${ }^{54}$ But spiritual forces, including curses, have been important agents in Taranaki history, well into the twentieth century. Two examples demonstrate this, giving a glimpse of a world in which Pakeha motivations, faiths and understandings are marginal, at best. Hohaia said that in the 1890s many of the tribunal claimants' great-grandparents were owners of blocks of land surveyed out of Crown grants. But this land was leased to Pakeha without the Maori owners being given details about the lease or rent. Hohaia said: 
This situation steadily deteriorated so that by the 1920 s our great grand parents had come to regard the situation imposed as a curse which caused families to disintegrate amidst suspicion and deceit. Many of our Tuupuna sold what land they had in order to break that curse. These are the effects of confiscation. ${ }^{55}$

The second example of the power of spiritual forces relates to the comet Rauhoto Tapairu and ancient petroglypths. Te Puniho, the sister pa of Parihaka, is the resting place for the Rauhoto. The comet, Hohaia relates, was moved to the pa in 1948 by a famous tohunga (healer), Te Ao Maarama 'who died two days later having said that this would be the outcome'. ${ }^{56}$ She was helped by Mrs Wiki Hau, aged in her nineties and still living in Oakura at the time of the hearings. The comet was moved because other important mauri kohatu (treasured stones) had been stolen and other tribes had interfered with Rauhoto 'hoping to remove her and therefore possibly [gain] the right to claim the mountain through the possession of Rauhoto. Upward of seventy people had died attempting to interfere with Rauhoto Tapairu who was regarded as extremely tapu indeed', Hohaia related.

The lethal, sacred comet streaks across the tribunal archives, illuminating new possibilities for writing Taranaki histories, histories that pre-date the arrival of Pakeha and, indeed Maori themselves. The absence of this kind of evidence in tribunal reports demonstrates the limits of that body's ability to 'rewrite' New Zealand history but the inclusion of this evidence in the tribunal archives offers opportunities to push these historical limits, to create new histories that move beyond an impoverished grievance framework.

\section{PARIHAKA IN AN ‘OTHER’ TARANAKI HISTORY}

In Australia, historians working for heritage bodies have started to record post-contact Aboriginal heritage sites in an effort to overcome an institutionalised bias towards 'prehistoric' Aboriginal sites. ${ }^{57}$ In New Zealand, the work of the tribunal, which can only report on things that happened after 1840 , has created a bias towards post-contact sites and stories. 'Prehistoric' Maori sites and events are absent in the Taranaki report, despite the tribunal's insistence that all claimants present two types of evidence: 'traditional' and 'historical'. ${ }^{58}$

In the tribunal's framework, historic events are the grievances that relate to things that did or did not happen after settlers arrived in New Zealand, specifically the actions or omissions of the Crown post-1840. While the tribunal strives to tell a Maori side to the 
story of colonisation, it is unable to narrate a Maori view of history, a story that begins hundreds of years before white settlement.

Yet the tribunal still requires Maori to include traditional history reports in their claims. A traditional history report has to explain who an iwi is and how that group of people relate to particular pieces of land. Traditional history reports require a detailed history of genealogy, geography, customary practices, warfare, alliances, migrations and so on, both pre- and post-1840. Specific histories are required for every site of special significance, whether it be a wahi tapu (sacred sites) or a mahinga kai (places used to grow or gather food). ${ }^{59}$ Claimants should interview kaumatua and kuia (senior men and women) and consult whakapapa books or other written sources in tribal possession. If possible, a researcher would search Native Land Court records and other archives. Traditional reports are not to discuss 'the direct actions of the Crown'. Such discussions - what the Crown did and what impact those actions had - are to be left for the historical reports, documents that are to be researched and written by 'professional historians'.

The Taranaki report includes none of this information. Instead, it opens with a narrative about the 'first purchases' of Maori land in the province that came to be known as Taranaki. Why, then, are traditional reports required? The answer, in large part, is that the tribunal uses these reports - along with the performance of the information they contain - as a way of assessing the quality of the evidence. In his fascinating reflection on histories and treaty claims, Tipene O'Regan describes the importance of packaging in the presentation of evidence. If a claimant gives a convincing performance - which would ideally include testimony in fluent Maori - they are seen as more credible than a witness who speaks little or no Maori. Yet, as Michael Belgrave has argued, 'the interweaving of oral and written sources of the last 170 years' means claimants find it difficult to share their traditional histories 'without reference to a range of written historical sources'. ${ }^{60}$ When traditions are shared, O'Regan cautions that this history is not tested by the empirical standards applied to academic history. Rather, it was either 'accepted or discounted on the basis of the manner in which it was presented'. ${ }^{61}$ For instance, in a revealing and sensitive article, the tribunal's chief historian Grant Phillipson has described how the behaviour of Moriori claimants during hearings on the Chatham Islands, 'the content of what was said and done, though outside the official hearing of evidence, was crucial to the Tribunal's view of the Moriori claim'. ${ }^{6}$

Until the information contained in Maori traditional history reports - the ones that are performed before the tribunal and the ones that are written and deposited in the archive - is accorded the same status as information contained in historical reports, it is tempting to argue that these reports are nothing more than a necessary performance of Maoriness. This performance is undoubtedly deeply meaningful for the small audience at the hearings but it has limited meaning beyond the marae or motel if it is not allowed to 
shape the history the tribunal writes. ${ }^{63}$ How might the story of Parihaka be altered if it is placed in a context provided by one such traditional history report?

The tribunal history of Taranaki opens with illegal purchases of land at Ngamotu, a settler action that breached the 'good faith' shown by Maori. The report then provides information about war and confiscation that sets the scene for 'the holocaust of Taranaki history' a catastrophe in which the invasion of Parihaka is a central event. But when it is free from the restrictive lens of Treaty breaches, Parihaka can occupy quite a different kind of time and space, one that is arguably more 'historical'. In his submission, Danny Keenan comments on the absence of historical monuments in New Plymouth, the region's capital, where Ngati Te Whiti people once lived and thrived. 'Today a complete townscape has replaced the historical landscape of Ngati Te Whiti,' Keenan said. Later, he reflected, 'New Plymouth city reflects little of its past; in its physical and architectural design, and in its administrative and human emphasis which has the deeper resonance of Europe, not New Zealand, it is thoroughly reflective of its present, a very long present that began in 1841.64

The 'present' that is dominated by the region's recent arrivals may be long but the past that pre-dated white settlement is far longer. In his traditional history, Hohaia located Parihaka in a history that began with Te Kahui Maunga, a people who were in Taranaki 'before even the mountain when Rua Tawhito (the Pouakai) and Rua Tipua (the Kaitake Ranges) stood and were associated with the creation story beginning "I noho a io I roto I te aha o te aao" wherein is told, the development of life and knowledge through the interplay of past and future. ${ }^{, 65}$ Part of this story tells the history Puke Te Whiti, a prominent hill in the Kaitake ranges that is visible from the coast, even as far south as Parihaka. Hohaia relates that this hill is a sentinel guiding the flight path of the comet Rauhoto Tapairu. As such, Puke Te Whiti is 'the guardian of the now and the crossing between the past and the future'. He said some people believe Te Whiti o Rongomai and his namesakes were named after the comet Rauhoto Tapairu and its flight path past Puke Te Whiti. ${ }^{66}$

Markers of the deep past depicted in this story were the ancient carved stones (petroglyphs) and tauranga waka ('monolithic statements carved into the landscape of the reefs') of Taranaki. The boulders were carved or pecked with eyebrow or spiral motifs and are believed to have been used to convey information about territory and relationships between groups. ${ }^{67}$ Hohaia uses these boulders to construct an interplay between past and future, a conversation that includes - but does not excessively dwell on - the invasion of Parihaka. He relates that some of these carved boulders were created by Kaahui Maunga people. One, Te Mapua, 'was in operation when Kupe circumnavigated the Island'. ${ }^{68}$ Te Mapua is at Te Ika Roa, one of the launching points for fishing boats that used to supply Parihaka maraes and families with food during the war. Hohaia relates that this launching point was used until the 1940 s. 
Mrs Louie Okeroa who is 93 and still lives at Te Ika Roa, was the lighter of the fires at night to guide her husband's 13-oar clinker in from fishing expeditions to and from offshore grounds. Her eldest son James Okeroa remembers well how the fish was allocated to various families who at that time had no boats on the water. During the war years these Parihaka fishing boats supplied the maraes and families with food which was otherwise difficult to come by. Boat sheds stood at many of the landings, complete with sleeping quarters for the crew. ${ }^{69}$

Another of the tauranga waka is Te Opu Opu, a launching place that is special for Parihaka and Ngati Moeahu people. A mauri (carved rock, life force, guardian or protector) was taken from here to Otakou, Otago in 1987 to commemorate the Taranaki men who died there during their imprisonment in the nineteenth century. Maori had authority over this place well into the twentieth century. Hohaia relates that in the 1950s elders Tom Inia and Wharepouri let Pakeha start fishing from there as long as they gave some of the catch to maraes. No commercial fishing was allowed. By the 1960s, Pakeha boats started to outnumber Maori ones at Te Opu Opu and 'today the Cape Egmont Boat Club enjoys almost exclusive use of the channel. ${ }^{70}$ Many club members were not aware of the 1950s agreement but senior Maori had suggested a kohatu (stone) and plaque to explain the significance of the place to Maori. Hohaia further suggested that the 1950s agreement should be put in the boat club's charter.

The stories associated with these landmarks demonstrate how Parihaka can be positioned in a dynamic web of meanings and connections far broader than that provided by 'the holocaust of Taranaki history'. In this Parihaka history, the settlement is one of sixty waahi tapu (sacred sites) around Taranaki. ${ }^{71}$ By drawing on the links between Parihaka and coastal fishing and garden settlements, Hohaia's testimony links Parihaka with the deep past (through the carved stones) and the near present (the agreement with the boat club). It encourages an understanding of Parihaka as a place that developed out of a complex history that includes the musket wars that predated white settlement in Taranaki, the work of Lutheran missionaries and the nineteenth-century land wars. The ongoing development and history of Parihaka includes twentieth-century events, such as local intercultural cooperation - and lack of cooperation - over fishing rights and farming and the hearings of the Waitangi Tribunal itself. The hearings are also a part of Taranaki history now too. The tribunal archives are a 'historic site' that is waiting to be explored, a starting point for new pasts, presents and futures. 


\section{ENDNOTES}

${ }^{1}$ I am drawing on Derrida's phrase about 'the violence of the archive itself, as archive, as archival violence', cited by Carolyn Steedman, Dust, Manchester University Press, Manchester, 2001, p7.

2 Bernard S. Cohn, Colonialism and Its Forms of Knowledge: The British in India, Princeton University Press, New Jersey, 1996, p3.

${ }^{3}$ For a discussion of the return to empiricism in the wake of challenges from postmodernism, postcolonialism and poststructualism, see Antoinette Burton, 'Epilogue: Archive Fever and the Panoptican of History', Dwelling in the Archive: women writing house, home and history in late colonial India, Oxford University Press, New York, 2003, pp137-144.

${ }^{4}$ Linda Tuhiwai Smith, Decolonizing Methodologies: Research and Indigenous Peoples, Zed Books and Otago University Press, Otago, London and New York, 1999, pp28-41.

${ }^{5}$ An excellent summary of the tribunal's first 25 years can be found in Paul Hamer, 'A Quarter-century of the Waitangi Tribunal' in Janine Hayward and Nichola Wheen (eds), The Waitangi Tribunal: Te Roopu Whakamana I te Tiriti o Waitangi, Bridget Williams Books, Wellington, 2004, pp3-14.

${ }^{6}$ For recent tribunal historiography see Michael Belgrave, Historical Frictions: Maori Claims and Reinvented Histories, Auckland University Press, 2005; Giselle Byrnes, The Waitangi Tribunal and New Zealand History, Oxford University Press, Auckland, 2004; Hayward and Wheen (eds), The Waitangi Tribunal Wellington, 2004; Michael Belgrave, M Kawharu and D Williams (eds), Waitangi Revisied: Perspectives on the Treaty of Waitangi, Oxford University Press, Melbourne, 2005; W.H. Oliver, 'The future behind us: the Waitangi Tribunal's retrospective utopia' in A Sharp and P. McHugh (eds), Histories, Power and Loss: Uses of the Past - a New Zealand Commentary, Bridget Williams Books, Wellington, 2001, pp9-31; Alan Ward, An Unsettled History: Treaty Claims in New Zealand Today, Bridget Williams Books, Wellington, 1999; Tipene O'Regan, 'Old Myths and New Politics' in Judith Binney (ed), The Shaping of History: essays from the New Zealand Journal of History, Bridget Williams Books, Wellington, 2001, pp15-38.

${ }^{7}$ For an analysis of 'victim narratives' before the tribunal, see Byrnes, Waitangi Tribunal, pp109-116.

${ }^{8}$ See Bain Attwood and Fiona Mogowan (eds), Telling Stories: Indigenous History and Memory in Australia and New Zealand, Allen \& Unwin, Sydney, 2001.

${ }^{9}$ Miranda Johnson, 'Honest acts and dangerous supplements: Indigenous oral history and historical practice in settler societies', Postcolonial Studies, vol 8, no 3, 2005, p262.

${ }^{10}$ See Te Miringa Hohaia, 'Ngaa Puutaketanga Koorero Moo Parihaka' in Te Miringa Hohaia, Gregory O'Brien and Lara Strongman (eds), Parihaka: The Art of Passive Resistance, City Gallery, Victoria University Press and Parihaka Pa Trustees, Wellington, 2001, pp43-65. Also Hazel Riseborough, 'Introduction to 2002 edition', Days of Darkness: The Government and Parihaka Taranaki 1878-1884, Penguin, Auckland, 2002, p15.

${ }^{11}$ One of the few works I am aware of that draws on evidence in tribunal archives is Danny Keenan, 'Ma Pongo Ma Whero Ka Oti' in B. Dalley and B. Labrum (eds), Fragments: New Zealand Social and Cultural History, Auckland University Press, Auckland, 2000, pp38-53.

${ }^{12}$ For a history of the Taranaki claims see Belgrave, 'Taranaki: Victims Triumphant' in Historical Frictions, pp217283.

${ }^{13}$ For a detailed analysis of these stories see Rachel Buchanan, 'Village of Peace, Village of War: Parihaka stories 1991-2004', PhD thesis, Monash University, 2005.

${ }^{14}$ Bain Attwood, 'Unsettling pasts: reconciliation and history in settler Australia' in Postcolonial Studies, vol 8, no 3, p253.

${ }^{15}$ Attwood, 'Unsettling pasts', Postcolonial Studies, p253.

${ }^{16}$ Dipesh Chakrabarty, Provincializing Europe: Postcolonial Thought and Historical Difference, Princeton University Press, Princeton and Oxford, 2000, p15.

${ }_{17}^{17}$ The Taranaki Report: Kaupapa Tuatahi, Wai 143, Wellington, Legislation Direct, 1996, Overview, p1.

${ }^{18}$ Taranaki Report, p2.

${ }^{19}$ Taranaki Report, p309.

${ }^{20}$ For an analysis of controversy that surrounded the report's release in New Zealand see Byrnes, Waitangi Tribunal and New Zealand History, pp149-152. For a broader discussion of the use of the word 'holocaust' within the Taranaki report and elsewhere to describe colonisation in New Zealand see David B. Macdonald, 'Daring to compare: the debate about a Maori "holocaust" in New Zealand', in Journal of Genocide Research, vol 5, no 3, 2003, pp383-403. With thanks to Ann Curthoys for this reference.

${ }^{21}$ Taranaki Report, p312.

${ }^{22}$ Macquarie, 2001, p825.

${ }^{23}$ H.M. Williams, Dictionary of Maori Language, p215 and p330. For Taranaki meanings see Michael Belgrave, 'Something Borrowed', in B. Dalley and J. Phillips (eds), Going Public: The Changing Face of New Zealand History, Auckland University Press, Auckland, 2001, p106.

${ }^{24}$ Taranaki Report, p7.

${ }^{25}$ Byrnes, Waitangi Tribunal, p140. 
${ }^{26}$ Dr Grant Phillipson, Preparing Claimant Evidence for the Waitangi Tribunal, Waitangi Tribunal, 1999, p1.

${ }^{27}$ Buchanan, op cit, pp41-82.

${ }^{28}$ Miringa Hohaia and Marlene Benson, 'Cape Egmont Lighthouse Reserve', case study presented at second Parihaka hearing, 22 October 1992, I11, Waitangi Tribunal Archives (hereafter WTA).

29 'Cape Egmont Reserve' report by Principal Keeper, Cape Egmont Lighthouse to G.C. Godfrey, secretary of the Marine Department?), 4/11/1929, document included in Hohaia, I11, p2, WTA.

${ }^{30}$ Letter to Under Secretary, Department of Marine, 15 July 1937, document included in I11, WTA.

${ }^{31}$ Memorandum to Secretary for Marine from O.H.Burns, Commissioner of Crown Lands, 22 May 1952, in I11, WTA.

${ }^{32}$ See Deborah Bird-Rose, 'Decolonizing the discourse of environmental knowledge', in G. Hawkins and S. Muecke (eds), Culture and Waste: The Creation and Destruction of Value, Rowmann and Littlefield, Boston, 2003, pp. 5372.

${ }^{33}$ Memorandum for The Principal Keeper, from W.C. Smith, Secretary for Marine, 9 June 1952, 'Cape Egmont Lighthouse Reserve' case study, WTA.

${ }^{34}$ See Dick Scott, The Parihaka Story, Auckland, Southern Cross, 1954 and Scott, Ask That Mountain, Auckland, Reed and Southern Cross, 1975. For a comprehensive political history of nineteenth-century events, see Riseborough, Days of Darkness.

${ }^{35}$ Taranaki Report, p212. The tribunal made similar observations about dealing 'not with a dry record or past habitations but with evidence that is lived' in its Whanganui report. Cited in Johnson, 'Honest acts and dangerous supplements', p264.

${ }^{36}$ Cited in the frontispiece of Tony Sole, Ngati Ruanui: A history, Huia Publishing, Wellington, 2005.

${ }^{37}$ For a discussion of the role of apologies in New Zealand, see Maureen Hickey, 'Negotiating History: Crown Apologies in New Zealand's Historical Treaty of Waitangi Settlements', Public History Review, vol 13, 2006, pp108-124.

38 Doug Graham, 'Iwi o Taranaki', statement from Office of the Minister of Justice, delivered by Tom Winitana on 17 October 1991 at Parihaka, see Record of Inquiry, Taranaki report, F17 (a), p.3, WTA.

${ }^{39}$ For comments on this see Rangikotuku Rukuwai, 'Parihaka: The Living Legacy' in Passive Resistance, pp69-70.

${ }^{40}$ Miringa Hohaia, letter to the Minister of Justice, re: Apology for Parihaka, 27 February 1992, Taranaki report, Record of Inquiry, F17 (b), WTA.

${ }^{41}$ This focus on an equality of status as part of the payment of a debt or making up for a wrong is a significant part of the Maori concept 'utu' or avenging a wrong. For a discussion of the complex meanings of this word see Oxford Dictionary of New Zealand English, pp877-878. Also Williams, Dictionary of Maori Language, p471. Utu is payment, satisfaction, a balancing up of accounts. In 1894, for instance, Tua-o-Rangi noted: 'Most born New Zealanders, whether fair or dark, have some conception of the meaning of the word utu... the ancient Maori did nothing for nothing... No man could accept service or gifts without requital and retain the esteem of his fellows; still less could he allow injuries to pass unavenged. Utu (value) he expected for the presents he made; utu (payment) he required for goods or purchase; utu (satisfaction) he exacted from hereditary foes and all whom he conceived [had] injured him.' p878, Dictionary New Zealand English.

${ }^{42}$ Graham to Hohaia, 9 April 1992, F17c, WTA.

${ }^{43}$ Ngati Mutunga and Her Majesty the Queen in right of New Zealand, 'Deed of Settlement of the Historical Claims of Ngati Mutunga: Initialled Deed of Settlement for Presentation to Ngati Mutunga', 14 December 2004, Wellington, Office of Treaty Settlements, 2004, p69.

${ }^{44}$ Lindsay Rihari Waitara MacLeod, opening evidence for Taranaki iwi claim, Parihaka, 16 October 1991, F11, WTA. All subsequent information from MacLeod is taken from this document.

${ }^{45}$ For a full version of this song, in Maori and English, see Hohaia, Passive Resistance, pp48-50.

${ }_{46}^{46}$ MacLeod, Evidence before second Parihaka hearing, 22 October 1992, Record of Inquiry, I1, WTA.

${ }^{47}$ MacLeod, first Parihaka hearing, F12, p3. Emphasis in original.

${ }_{48}^{48}$ MacLeod, F12, p4.

49 'My name is Donald Hugh McDonald - My Tribe is Ngati Mutunga', submission at Owae Marae, 3-6 September 1990, WTA.

50 'Muru Raupatu - Taranaki', Documents to the end of the first hearing, 7 September 1990, A17, WTA.

${ }^{51}$ Dr Ngatata Love, A17 (a), WTA.

${ }^{52}$ Peter Moeahu, 'Muru Raupatu', A17, WTA.

${ }^{53}$ Moeahu, p9. Moeahu's extraordinary submission is structured like an epic poem with a series of statements under various evocative headings.

${ }^{54}$ There are new signs that absences in tribunal reports may be compensated for in tribal Deeds of Settlement. The 2004 Ngati Mutunga Deed, for instance, opens with a whakatauaki (saying) and karakia (prayer) about the beginnings of life. Tribal songs and sayings are part of the 'historical account' presented in this document.

${ }^{55}$ Hohaia, 'Opening for Taranaki iwi', A17, p8, WTA.

${ }^{56}$ Hohaia, 'Waahi Tapu', site 28, F14, WTA. 
${ }^{57}$ For a discussion of issues around Aboriginal heritage see Denis Byrne and Maria Nugent, (eds), Mapping Attachement: a spatial approach to Aboriginal post-contact heritage, Department of Environment and Conservation, Sydney, 2004.

${ }^{58}$ Phillipson, Claimant Evidence, p3 and p16. A kaumatua (elder) sits on every tribunal and it is this person's job to assess traditional evidence. The historical evidence is assessed by a 'professional historian'.

${ }^{59}$ Philipson, Claimant Evidence, p13.

${ }^{60}$ Belgrave, 'The Tribunal and the Past' Belgrave et al (eds), Waitangi Revisited, p47.

${ }^{61}$ Tipene O'Regan, 'Old Myths' in Binney (ed), Shaping History, pp22-23.

${ }^{62}$ Phillipson, 'Talking and Writing History: Evidence to the Waitangi Tribunal' in Hayward (ed), Waitangi Tribunal, pp44-45.

${ }^{63}$ For stories about the emotional tone of tribunal hearings, see Boast and Phillipson's articles in Hayward's Tribunal collection, pp53-66 and pp41-52.

${ }^{64}$ Danny Keenan, 'Ngati Te Whiti Muru me te Raupatu Waitangi Tribunal presentation', Documents to the end of the fourth hearing, 12 April 1991, D14, WTA. The emphasis is mine.

${ }^{65}$ Hohaia, 'Submission concerning traditional history presented by Milton Hohaia on behalf of Taranaki iwi, Documents to the end of the sixth hearing, 17 October 1991', F12, WTA. For a further elaboration of Maori creation stories and an explanation of how they influenced the teachings of Te Whiti and Tohu see Hohaia Passive Resistance, pp. 43-44. For stories linked particularly to the history of Maunga Taranaki, see Hohaia, 'The Foundation Story' in Te Maunga Taranaki: views of a mountain, Govett Brewster Art Gallery Publications, New Plymouth, 2001, pp9-15.

${ }^{66}$ Hohaia says others believe the prophet was named after the comet 'Te-Auahi-Tu-Roa'. In the Williams Maori dictionary, 'whiti' has at least four meanings. The first set of meanings are all concerned with transformation: to cross over, to reach the opposite side, to change, to turn, to pass through, to return present. The second meaning is shine or shine upon, ra-whiti is sunrise. The third set of meanings are connected with alarm, surprising and awakenings. The fourth is to relate or recite a charm or verse, pp497-98.

${ }^{67}$ Nigel Prickett, 'A recently discovered petroglyph at Omata, Taranaki', New Zealand Archaeological Association Newsletter, vol 24, no 3, September 1981, pp198-201. This paper presented by as part of the testimony of Hohaia on 'Nga Mauri Kowhatu o Taranaki', documents to the end of the sixth hearing, 17 October 1991, F16 (a)-(e), WTA. In his introduction to this material Hohaia explained that much had been said about this carved rocks by Pakeha. 'Perhaps if the confiscations had not destroyed the Maori institutions to the point it has, much more could be said now without hypothesis or the regurgitation of myths created by Pakeha.' In the absence of oral tradition about the origins of these treasures, the connection Taranaki Maori now felt with them was a spiritual one, a link with their ancestors.

${ }^{68}$ Kupe is the Maori discoverer of New Zealand. A recent exhibition at Te Papa Tongarewa Museum of New Zealand placed Kupe next to Cook as a discoverer. 'Voyagers', 29 June 2002-19 January 2003.

${ }^{69}$ Hohaia, 'Tauranga Waka', F15, WTA, p2.

${ }^{70}$ Hohaia, F15, WTA, p2.

${ }^{71}$ Hohaia, 'Waahi Tapu', F14, WTA. 